\title{
Image (of God) as ethical injunction: A social-scientific perspective
}

\author{
P van Staden \\ University of Pretoria \\ Temporary part time lecturer: \\ Department of New Testament Studies (Section A)
}

\begin{abstract}
Taking cognizance of the fact that language - especially metaphorical language - can be expressive of deeplying cultural or religious symbol sets in man, the study explores the possible original content of the

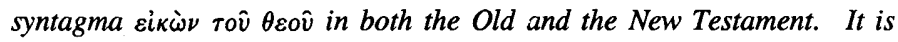
argued that there is a definite shift in the symbol set of which the concept (metaphor) 'image of God' is expressive. Whilst the Old Testament usage of the term probably attests to the conviction that humankind is part of the genus God and may even resemble him physically, the New Testament substitutes Jesus Christ for man as the primary carrier of the 'image of God'. Humankind in general does not reflect that image any more. It is only to be found in those who through faith in Jesus Christ regain the image of God. Our thesis is that the concept of 'image' is to be regarded as much an ethical injunction as it is an ontological statement. The faith of adherents to the community of believers finds expression in distinctive behavior - that is, in conduct that clearly identifies them as reflecting the image of God.
\end{abstract}

\section{INTRODUCTION}

\subsection{Defining the issue}

The expression 'image of God' seems to have a fascination for theologians totally disproportionate to the number of times it appears in the Bible and to its apparent weight.

* This essay is a reworked version of the public lecture held at the St Andrews Conference on New Testament Interpretation and the Sosial Sciences, The University of St Andrews (Scotland), 29 June to 3 July 1994. 
The sheer volume of monographs, articles, and theological discussions of all kinds published on this subject is nothing less than astounding. Discussion of and debate on the meaning of the expression can be found in the works of Philo ${ }^{1}$, in Gnosticism², in the New Testament, in Rabbinic sources, in the Patristic literature ${ }^{3}$, in Medieval Scholasticism and the Renaissance ${ }^{4}$, in Catholicism and Protestantism ${ }^{5}$ and continues unabated into the present time. These contributions can be described as either exegetical or dogmatic, or both 6 .

We encounter the expression for the first time in the Old Testament in the Priestly document's version of the creation in Gn 1:26-27. Thereafter it appears in Gn 5:1 and 9:6 in the same meaning, and in Gn 5:3 where it is applied to Adam's son, Seth, being born in the image of his father. The expression does not occur in the Old Testament again with reference to man as the image of God.

In the New Testament the expression occurs in 2 Cor $4: 4$ and Col 1:15 where it is interpreted and applied in a Christological sense. It is not man any more, but Christ who is described as the 'image of God.

From the beginning the discussions revolved around the question whether the content of the 'image' should be taken as substantial or relational. In other words, should the image of God in man be thought of as residing in the substance or essence of man, and if so, what would it consist of? Or should it be understood as a relational issue that manifests itself in man's relation to God, so that the image is not a given that resides in humankind, but a reality that is only realized in and through faith (cf Hill 1984:202; Wilson 1974:356-357, referring to Karl Barth's concept of the analogia relationis)?

\subsection{Purpose of the study}

The purpose of this study is not to recount in full or even summarize previous work that has been done on the subject. It is also not to take up the debate about the substantial/relational controversy. What is clearly important throughout the history of investigation of the concept 'image of God,' is the question of its meaning. How should it be interpreted, and what are the practical implications that could be drawn from such meaning either for a better understanding of God as the prototype or original (Horst 1950:260) of the 'image,' or of man in terms of both ontological and behavioral categories?

The perspective we wish to offer is one that relates to the meaning of the concept 'image of God' as relevant to a life of faith. In other words: Why should the idea of existing in the image of God have any significance for the believer? And what would the moral and behavioral consequences be of the acceptance of that significance? This is not a new question - many such consequences have been indicated by other authors. 
What is thought to be new, however, is the explication of the concept of the 'image of God' by employing a model taken from the social sciences - specifically, a model by means of which the concept of the 'image' is treated as a symbol.

\section{HISTORY OF RESEARCH}

From the outset the concept 'image of God' seems a controversial and therefore ambiguous one. The strongly worded taboo on making and worshiping any (graven) image of God (Ex 20:4) has played a major role in forming the identity and structure of Israelite society and the form and content of cultic practices and rituals. Religious life in general was dominated by this principle that God cannot be represented by anything in creation, therefore any such practices as making likenesses or images were defined as idolatry and expressly forbidden (cf Wildberger 1965:257-258; Hill 1984:197). Von Rad (1964:381) states in this regard: 'The conviction that Yahweh is not to be depicted in the form of an image is intrinsic to true Yahweh worship.' This is indicated explicitly in Dt 4 in the following texts ${ }^{7}$ :

12 Then the LORD spoke to you out of the midst of the fire; you heard the sound of words, but saw no form; there was only a voice.

15 Therefore take good heed to yourselves. Since you saw no form on the day that the LORD spoke to you at Horeb out of the midst of the fire, 16 beware lest you act corruptly by making a graven image for yourselves, in the form of any figure, the likeness of male or female, ...

23 Take heed to yourselves, lest you forget the covenant of the LORD your God, which he made with you, and make a graven image in the form of anything which the LORD your God has forbidden you. ${ }^{24}$ For the LORD your God is a devouring fire, a jealous God.

This strict law may account for the fact that the concept of man being made in the image of God is confined in the Old Testament to three occurrences in the book of Genesis $(1: 26-27 ; 5: 1 ; 9: 6)$ and one corroborative instance in Ps 8:6-7.

In order to facilitate this short overview and for the sake of clarity, we shall discuss very concisely the main arguments in the various sub disciplines indicated below. 


\subsection{Old Testament}

In the account of the creation of man (according to P), it is stated that man was created in the 'image' and 'likeness' of God. The Hebrew terms used are צִ צֶלוּת respectively 8 . In a discussion of the usage of the term in the Old Testament, Wildberger (1976:558) $)^{9}$ is of the opinion that the historical thought world should be taken into account in the allocation of meaning:

Dabei ist noch deutlich das magische Bildverständnis zu fassen: indem man die Abbilder wegschafft, hofft man, sich der Sache selbst entledigen zu können ...

צֶ ist also mehr als 'Abbild' nach unserem Verständnis: in ihm ist das Abgebildete selbst präsent, im Verfügen über das Abbild kann man über das Abgebildete seine Macht ausüben.

He also indicates, however, that in the case of the development of meaning over time, such a term could gain some flexibility of meaning (Wildberger 1976:558; see also Porteous 1962:683).

There seems to be considerable agreement amongst scholars that 'image' would have been understood in a material sense in ancient times. In other words, the 'image' could, at least partially, be located in some physical resemblance, such as the upright stature of man. Porteous (1962:682) ${ }^{10}$ remarks:

The primary reference is to concrete resemblance, but we must credit the writer with some intention to convey an abstract idea - viz, that of human personality in its relation to God.

As to the meaning of the expression, there is a variety of scholarly opinion. According to Porteous (1962:683) some take it in a most strictly concrete sense to mean (a) that man is a concrete image of God in terms of a literal physical resemblance, or (b) that he is made after an actual concrete model or image of God. Others offer a purely spiritual interpretation, using words like 'personality,' 'self-consciousness,' 'immortality,' 'reason,' 'ability to rule,' 'free will' and 'moral capacity.'

While some scholars regard the expression as part of the anthropomorphic way of speaking about God ${ }^{11}$, others consider it to be a theomorphic (cf Berkhof 1973:71) way of speaking about man. Wildberger (1965:248) gives the following perspective: 
Das Alte Testament scheut sich zwar nicht, sich in seinem Reden von Gott kühner Anthropomorphismen zu bedienen. Nie aber redet es davon, dass Gott einen Körper hat, geschweige denn dass der Versuch unternommen würde, dessen Gestalt zu beschreiben.

\subsection{Rabbinic}

An important source of ancient Jewish thought can be found in the Babylonian Talmud, which contains rabbinical discussion between the 2nd and 5th centuries A D (cf Horowitz 1979:181).

The idea that the human being was created in the image of God is seen as lying at the root of the Rabbinic teaching concerning man (Cohen 1932:67). Kittel (1964:392) asserts that 'Rabbinic theology found the divine image much less of a problem than Philonic exegesis and later Christian theology'. According to Fossum (1985:208), however, the rabbis regarded Gen 1:26 as a 'dangerous text'. He refers to a tradition ascribed to $\mathrm{R}$ Jonathan in the beginning of the third century $\mathrm{C} E$ where Moses, in writing down the works of creation, is imputed to have queried the statement 'Let us make man' by asking: 'Sovereign of all, why do you provide the heretics with an argument,' upon which God replied: 'Write! Whoever wishes to err, let him err' (Gen Rab 8,8)! Before the middle of the third century the interpretation was that the expression "Let us ...' was addressed to the angels. The problem apparently was with the plural 'Let us make,' which furnished the heretics with the argument that the angels should be regarded as God's co-creators (cf Fossum 1985:211; Kittel 1964:392). By the end of the third century Rabbinic interpretations explained the cohortative as addressed to the 'works of heaven and earth', the 'works of each day', the Torah or to 'his heart' (himself) (cf Fossum 1985:210; Kittel 1964:329).

In an excellent article on the inclusion of women as bearers of the image of God, Horowitz (1979:189) refers to the Rabbinic interpretation of the concept:

Several rabbis had said that man was in the image of God in that he stands upright, speaks, understands, and sees, as do the ministering angels, and that he is like lower animals in that he eats and drinks, procreates, excretes, and dies (Gen Rab 8.3-11).

She also quotes an interesting item in Rabbinic interpretation: 
A repeated Talmudic explanation for the single formation of man and woman is the hermaphroditic one: adam was bisexual

and:

(Horowitz 1979:184)

In the doctrine of the Kabbalah, the medieval mystical teaching that acquired an ever-increasing influence on Jewish thought ... and had a strong impact on Christians during the Renaissance, the notion of adam as a hermaphrodite was expanded to include the corresponding notion that the God in whose image adam was formed, has both a male and a female dimension.

(Horowitz 1979:185)

These references serve to indicate that discussion on this issue was extensive and sometimes esoteric. Horowitz (1979:181) points out:

The portions of the rabbinic tradition which relate to the original nature of mankind are primarily haggada, folklore, rather than halakah, legalistic controversy. Such stories were often meant to be taken 'with a grain of salt,' and there was no attempt by rabbis to consolidate contradictory versions of the same story into a clearcut system.

\subsection{New Testament}

The few times that the New Testament takes up the Genesis expression of the 'image of God,' it is almost without exception applied to Jesus Christ (cf Eckert 1989:343; Wilson 1974:357). He is in a special way, like none other, the image of God. This in itself signifies a deviation from the creation account in Genesis 1:26-2712.

\subsubsection{Relevant passages}

The specific Old Testament (LXX) syntagma $\varepsilon i k \grave{\omega} \nu$ rov $\theta \varepsilon o \hat{v}$ appears in the New Testament in 2 Corinthians $4: 4$ and in Colossians 1:15. In both these instances the $\varepsilon i k \omega \nu$ refers explicitly to Jesus Christ.

The concept aiso appears in Hebrews 1:3 in an eulogy on Christ; the Gospel of John 14:9-10 with Christ as the 'face' of God; renovation into the image of Christ (Rm 8:29) through regeneration (Eph 4:24) and lifelong transformation (2 Cor 3:18; Col 
3:10) (cf Jones 1962:556; Porteous 1962:684-685; Kittel 1964:395-397; Hill 1984:201202; McCasland 1950:85-88; Wilson 1974:357; Plantinga 1988:56-57). Some scholars consider Phlp 2:6 to be expressive of the same concept (cf Plantinga 1988:56; Wilson 1974:357), but Steenburg (1988) disagrees.

In two instances the concept of the 'image' appears to refer to man, rather than Christ. The first is 1 Corinthians 11:7 in the context of Paul's directives on headgear in worship. The second instance is James 3:9 in the context of swearing at people made in the likeness of God.

In 1 Cor 11:7 the term eik $\omega \nu$ is applied to man, who is described as the 'image and glory of God.' The question arises: Does it follow that Paul here reverts back to the Genesis account whereby man is created in the image of God, and is Christ excluded from this scenario?

Paul's explication should be understood against the background of a query by the Corinthian church about the conduct of women in the church, in terms of dress (headgear). It is clear from the passage that Paul has some trouble formulating a consistent argument. On the one hand, he presents the church as a new community within which new rules apply about the status of man and woman. In Christ they are undifferentiated, one and the same in terms of status and worth (1 Cor 11:11-12; Gl $3: 28$. See also Col 3:11, which supports the point even though women are not explicitly mentioned). On the other hand Paul seems to feel obliged to establish some order in the meetings of the church of Corinth (cf 1 Cor 11:16, 20-22; 14:26-44, especially vv 33 and 40). In an effort to establish this order he uses a theological argument, creating a frame of reference within which the issue should be adjudicated, and providing a norm which should be applied in this particular instance.

The frame of reference is the creation order in Genesis 1 and 2. On the basis of $\mathrm{Gn}$ 2:18-24 Paul argues that - despite their equality 'in Christ' within the church - man has a primary position over and against woman. He describes the hierarchical creation order as God $\Rightarrow$ Christ $\Rightarrow$ man $\Rightarrow$ woman (1 Cor 11:3; cf Barrett 1971:249; Conzelmann 1969:215-216; Wendland 1972:92,94). To this natural order everyone should adhere. Malina (1981:115) describes Paul's position as follows:

The customs Paul envisions as binding Christians in their reciprocal interactions derive from the activity of God's power, the Spirit, within those communities .... However, Paul also insists that his fellow Christians not confuse societal realities (the laws of the Greek, Roman and Jewish world) with the open access to God and the 'oughts' flowing from this access as symboled in Christ. Rather, Christian custom and societal law now stands in 
dialectical opposition .... On the one hand, openness to God and neighbor is necessary and can be fully expressed in Christian gatherings, but in line with the customs thus far developed in the Christian churches (thus 1 Cor 11:2-16; note v.16: 'we recognize no other practice, nor do the churches of God'). On the other hand, the opinion of outsiders (societal reality, prevailing law) is to be taken into account.

In the use of the term $\varepsilon i \kappa \omega \nu$ Paul in 1 Cor 11:7 is referring to Gn 1:27. His intention is not, however, to explicate the meaning of man's creation in the image of God, but rather to support his argument about man having a higher position than women in the natural order ordained by God. On the basis of this argument Paul is able to claim that women are subordinate to men and should show that subordination by wearing headgear in the church meeting (cf also Conzelmann 1969:216). The norm which Paul formulates, is that a woman should not shame her husband by attending church with an uncovered head. He only says that, though, after he described the hierarchical order within which man is subordinate to Christ, and Christ to God. In a roundabout way Paul seems to be saying the same thing that he says in 2 Cor 4:4, namely that Chrisi is the image of God, and man is the image of Christ. If that is correct, then Paul is consistent in his argument.

The only instance in the New Testament where the 'image' is taken up in the Genesis 1:27 meaning of man being created in the image of God, is the one in James 3:9. It should be noted, however, that the term $\varepsilon i \kappa \omega \nu$ is not used by James, but rather the term $\dot{o} \mu$ oi $\omega \sigma \iota$.

\subsection{Context}

Col 1:15-20 is acknowledged by most scholars to have a hymnic character (cf inter alia Pokorný 1991:57; Wilson 1974:357; Lohse 1977:77; Conzelmann 1976:182). In Col 1:15 the Son (of God) is said to be the 'image of God,' perhaps in the sense of making visible the 'full nature of God' (Col 1:19), which is by definition not knowable to the human senses or mind. The efficacy of the Son being the 'image' of God is that through his death he will bring the believers before God - holy, pure and faultless (Col 1:22). This can be accomplished because Christ as 'image' can make the nature of God operable in the believer by being the true mediator - firstly as the embodiment of the essence of God: 'The full content of the divine nature lives in Christ, in his humanity' (Col 2:9). Secondly, by becoming one with Christ through faith, the believer gains insight into the wisdom and knowledge of God. Christ, the 'visible likeness of the invisible God' (Col 1:15), makes known God's secret to his people. The 
secret is 'that Christ is in you, which means that you will share the glory of God' (Col $1: 27)$. It seems clear that Christ, by being the 'image of God,' is himself the secret of God (Col 2:2): 'He is the key that opens all the hidden treasures of God's wisdom and knowledge' (Col 2:3). Van der Watt (1988:29) concludes from his structural analysis of Col 1:15-20 that Christ is alternatively described by terms denoting status and function. From this he deduces that Christ is the image of God because he has God's status and function in respect of creation and redemption (cf also Pokorný 1991:69).

The context of 2 Cor 4:4 is what Eckert (1989:344) sees as revelations 'über die heilsentscheidende Offenbarung der Doxa Gottes, die sich in Christusgeschehen ereignet hat und im Evangelium aufleuchtet'. Christ is associated with light, and through him God lets the light shine in our lives as well. Here also one finds the definite indication that Christ as image is the way for man to get close to God.

\subsection{Conclusions}

One can briefly state that speculative theology had for a long time tried to pinpoint this 'image of God' in man. Discussions have ranged far and wide as to the meaning content and concrete implications of man being created in the image of God. Some innovative analogies have been found for the concept of the image in an attempt to understand it better (cf Kline 1978). During its history of investigation the concept has gained such prominence that there is even a doctrine of the image of God.

\section{SOCIAL-SCIENTIFIC MODEL}

Having identified the relevant texts in the Old and the New Testaments and having provided an introductory (and abbreviated) survey of the broad lines of thinking on the concept of the imago dei, we now turn to the proper subject of the paper. At this stage the different interpretations of the concept that man is created in the image of God are not immediately relevant. What concerns us is the presentation of the concept of the 'image of God' in both the Old and the New Testament, in respect of which two observations should be made:

* The self-evident manner in which the expression is used, with little or no explanation as to its meaning content and/or reference, is noteworthy.

* The history of the investigation of the expression in exegetical and applied (e $\mathrm{g}$ medical ethics, cf Rogers 1988) studies has proven to be inconclusive as far as determining a definite meaning is concerned. The concept is apparently resistant to any exhaustive definition.

What should one conclude from such observations? Possibly two things again:

ISSN 0259-9422 = HTS 51/2 (1995) 
* Firstly, that the concept was so self-explanatory and self-evident in terms of content to its users that there was no need to define its meaning.

* Second, that the interpretation of the concept was done on a pre-rational and affective level, so that the meaning was intuitively understood and could not therefore be verbalized in definitive terms.

In case of the first observation and its corresponding conclusion the best results in the quest for the meaning of the concept would probably be achieved by employing those methods that have been used up to now, namely careful textual analysis (exegesis) and a comparison with relevant extra-biblical material from the surrounding socio-cultural matrix (e g, applicable religious and other texts, artifacts, archaeological evidence, etcetera) ${ }^{13}$. Through such means one could probably determine the presumed 'selfevident' meaning with some measure of success.

However, given the fact that no adequate definition of the concept could be arrived at up to now, and given the conclusion above that the concept may have functioned on a pre-rational, intuitive level in antiquity, some other method may be considered by means of which a better understanding can be facilitated. What is proposed here, then, is a different angle from which to approach the problem, namely by employing a conceptual model from the social sciences. The choice of the model is based on the recognition that the expression 'image of God' does not signify a simple one-to-one similarity (be it confined to some aspects) between man and God. The concept should rather be taken to be the symbolic expression of a more complex relationship. To be more specific, this is a model that reflects an approach to the analysis of cultures in terms of the key symbols which embody and reflect the deepest convictions of a given culture.

\subsection{The symbolic mode}

... symbolic cognition plays a greater role in some cultural systems than in others, and ... understanding this mode of thought (which is not rational thought) is the key to understanding ritual and mythic symbolism.

(Foster \& Brandes 1980:6)

In a discussion on the meaning of symbols, Foster \& Brandes (1980:3) start out from the premise that symbols convey some kind of sense: 'Although we may vary individually in our evaluation of the kind of serise conveyed by particular symbols - good 
sense or utter nonsense - we cannot but agree that to their users every symbol makes some kind of sense or it would neither come into use nor be perpetuated'. They distinguish three components (types) in symbolic meaning:

* Denotation (or reference).

* Connotation (or figuration).

* Intentionality (or motivation).

Reference is made to the work of Sperber in the same volume, who has shown that denotation (reference) and connotation (figuration) 'serve separate functions, require different systems of interpretation and description, and complement or supplement one another in human activities' (Foster \& Brandes 1980:3).

An important point is made by Foster \& Brandes (1980:3) concerning another premise, namely that symbolism is more than representation. It really is a representational process 'that depends both for its creation and for its replication on human interaction within a culturally defined setting. This makes social context of crucial importance in determining and interpreting symbols'. Taking this remark together with the argument of Bolinger (1968, referred to by Foster \& Brandes 1980:4) that intonational universals are as important as phonology in establishing meaning, the importance of the intuitive experience of meaning is emphasized. This is expressed convincingly in the following quotation:

Intentionality seeps through and affects the interpretation of denotational messages by differentiation of pitch level, the forcefulness with which syllables are uttered, and the rhythm with which linguistic units are temporally spaced. The speaker thus inserts himself and his feelings about events into the sense of the message that he is purveying. This invasion is neither sense as 'rationality,' nor nonsense as 'lack of meaning'. ... It is affectively rather than referentially evocative, and the way that the message is produced or interpreted is dependent upon real or imagined relationships between speaker, listener, and the context of situation. The listener reacts to the connotations of the inflection at the same time that he or she is attending to the denotative meaning of the sentence that is being heard, which the connotative message sometimes contradicts.

(Foster \& Brandes 1980:4-5, referring to Bolinger) 
Affect thus has an important role to play in determining symbolic meaning. Symbol is defined connotatively. Foster (1980:371) ties symbol and culture close together: 'The history of symbolic expression is the history of cultural representation'. She maintains that, despite considerable diversity in definitions of symbols and symbolization, there seems to be substantial agreement on some basics. Those, as well as some of her own insights, are formulated below as a definition in four statements of what symbolism is:

* Symbolism is a representative act.

* Symbols are generally more concrete than what is symbolized.

* There is never a simple, direct relationship between symbol and what is symbolized. Symbols are complexly interrelated through analogical bonds.

* The relationship between symbol and meaning is never arbitrary.

Concerning the last (fourth) of the preceding statements, Foster (1980:372) points out that the arbitrariness that seems to be indicated by the wide range of cultural variation described by anthropologists is a 'surface phenomenon that masks the strict laws by which symbols are organized into systems and structures.' She postulates the existence of symbolic universals - upon which this overt or behavioral level is based - whose functional interrelationships can lead to change (cf Foster 1980:372). One of the basic assumptions concerning the symbolic universals is that metaphor is the major law of symbolic organization and growth. Foster (1980:372) elaborates:

In essence, this means that all symbolic codes, including language, are complexly organized at a deepstructural level in ways that are nonarbitrary. The law of metaphor is a biological necessity for the cognitive functioning of Homo sapiens. It creates and maintains culture by discriminating likenesses and using them as the basis for establishment of cognitive classes that determine action.

In a detailed and rather complex discussion on symbolic modes, Foster (1980:373-375) differentiates between the overt or behavioral level where symbolic relationships have a temporal dimension, and a covert deepstructure level. The first is called the syntagmatic dimension or mode, and the second the paradigmatic dimension of symbolism ${ }^{14}$. The paradigmatic mode is organized around metaphor, which implies a relationship of partial likeness. Because of the power of metaphor the possibility of virtually infinite 
paradigmatic addition is created, and culture and its subsystem, language, become open-ended ${ }^{15}$. In the syntagmatic mode, on the other hand, the main focus is on problem-solving ${ }^{16}$. Foster (1980:375) concludes, with reference to the example in the previous endnote, that paradigms tend toward symmetry and thereby seem to exert an unconscious constraint on the change potential where such symmetry has been established. She (1980:375) deduces from the work of Paul Kay (1971) that there is a repetitive formation of similar paradigm systems,

each starting from a unique beginner, or all-inclusive taxon of taxons (a taxon is a class), and progressing through a sequence of less inclusive taxa to terminal taxa, which classify the most specific entities that the system admits. A taxon such as the English unique beginner plant progresses more or less symmetrically through a succession of less inclusive taxa, such as tree, vine, grass, and so on, each with a similar spread of terminal taxa.

To this she adds:

Language provided man with a powerful tool for classification, but classification is expressed in many symbolic ways other than language. National flags are symbols .... The strength of any such symbol lies in its power to classify, to subsume ... Christians are represented by the Cross and Jews by the Star of David. These symbols are unique beginners even though visual rather than verbal.

(Foster 1980:375; italics mine)

To conclude this section: If the expression 'image of God' is taken as metaphorical language which signifies partial likeness and forms the core of the paradigmatic symbolic dimension (i e, the deepstructure mode), the question arises as to what exactly is symbolized by what symbol. It is to the resolution of this problem that a model will be constructed and applied in the following sections.

\subsection{Model of 'key symbols'}

According to Ortner (1973:1338) the notion of 'key symbol' is used in anthropological analysis: 'It analyzes phenomena which have been or might be accorded the status of 
key symbol in cultural analyses, categorizing them according to their primary modes of operating on thought and action.' While the term 'key symbol' is attributed to Ortner (cf Foster 1980:376), it is not a novel idea (cf the reference to Kay's 'unique beginners' in 3.1 above). The concept to which it refers has been known and applied for quite some time under different names, all with reference to the perception 'that each culture has certain key elements which, in an ill-defined way, are crucial to its distinctive organization' (Ortner 1973:1338) ${ }^{17}$. The next logical question is, of course, how to identify such 'key' or 'core' symbols in any cultural system.

\subsubsection{Methodology for identifying key symbols}

Ortner (1973:1338-1339) describes two methodological approaches that are used to establish certain symbols as 'key' or 'core' to a cultural system.

The first, which she indicates as the less commonly used one, analyzes the system or its domains to identify its underlying elements, such as cognitive distinctions, value orientations, et cetera. Having achieved this, the method proceeds by searching for 'some figure or image which seems to formulate, in relatively pure form, the underlying orientations exposed in the analysis' (Ortner 1973:1338) ${ }^{18}$.

The second methodological approach does not start from a systemic analysis, but rather from the observation in a real life situation of something which seems to be an object of cultural interest. Ortner (1973:1339) points out that the identification of some symbol as an object of cultural interest need neither be mysterious, nor intuitive. She lists the following five 'reasonably reliable indicators of cultural interest,' by means of which one should be able to find most key symbols:

* The natives tell us that $\mathrm{X}$ is culturally important.

* The natives seem positively or negatively aroused about $\mathrm{X}$, rather than indifferent.

* X comes up in many different contexts. These contexts may be behavioral or systemic: $\mathrm{X}$ comes up in many different kinds of action situation or conversation or $\mathrm{X}$ comes up in many different symbolic domains (myth, ritual, art, formal rhetoric, etc).

* There is greater cultural elaboration surrounding $\mathrm{X}$, that is, elaboration of vocabulary, or elaboration of details of X's nature, compared with similar phenomena in the culture. 
* There are greater cultural restrictions surrounding $\mathrm{X}$, either in sheer number of rules, or severity of sanctions regarding its misuse.

Ortner (1973:1339) accepts that there may be more indicators of the key status of a symbol in a culture, but maintains that any of those above should be enough to identify a key symbol. She makes the important point that anything by definition can be a symbol, that is, a vehicle for cultural meaning, and that the anthropological literature indicate that almost anything can be a key as well. Some of these symbols are intuitive (e $\mathrm{g}$, the cross of Christianity, the national flag, etc), while others are more 'public'19. While the meaning of symbols in a culture is intuitively known by participants in that culture, there will invariably arise occasions where one needs to be able to explain a meaning in a more definite and descriptive fashion. Such a need might be provided for by the classification of symbols, which is discussed in the following section.

\subsubsection{Symbol categories}

The vast array of symbols in any culture, with the possibility of creating ever more through the power of metaphor (cf 3.1 above), makes it almost impossible to describe them properly if some order cannot be imposed on them. This is what Ortner (1973:1339) tries to do when she proposes a major breakdown among the various types of symbols along a continuum that has at its one end 'summarizing' symbols, and at its other end 'elaborating' symbols ${ }^{20}$. She describes these two types of symbol as follows:

Summarizing symbols ... are those symbols which are seen as summing up, expressing, representing for the participants in an emotionally powerful and relatively undifferentiated way, what the system means to them. This category is essentially the category of sacred symbols in the broadest sense, and includes all those items which are objects of reverence and/or catalysts of emotion - the flag, the cross ....

Elaborating symbols ... work in the opposite direction, providing vehicles for sorting out complex and undifferentiated feelings and ideas, making them comprehensible to oneself, communicable to others, and translatable into orderly action.

(Ortner 1973:1339-1340). 
She explains a summarizing symbol as embodying a conglomerate of ideas and feelings, for which it stands all at once. This type of symbol does not encourage reflection on the logical relations among these ideas, nor on their logical consequences as they are played out in social actuality over time and history (Ortner 1973:1340). Summarizing symbols operate to compound and synthesize a complex system of ideas to create a unitary form which represents the system as a whole (the so-called 'sacred' symbols, cf 3.2.2 above).

Ortner (1973:1340) maintains that elaborating symbols acquire central status in the culture because of their capacity to order experience. They could be typified as essentially analytic. They are very rarely classified as sacred in the sense of being objects of respect or focal points of emotion: 'their key status is indicated primarily by their recurrence in cultural behavior or cultural symbolic systems' (Ortner 1973:1340).

Symbols exhibit two modes of elaborating power. First, conceptual elaborating power in respect of which they are valued as a source of categories for conceptualizing the order of the world. Second, action elaborating power in respect of which they are valued as implying mechanisms for successful social action. Ortner (1973:1340) defines the two basic and interrelated functions of culture in general as follows:

to provide for its members 'orientations', that is, cognitive and affective categories; and 'strategies,' that is, programs for orderly social action in relation to culturally defined goals.

She takes over the concept of 'root metaphors' from Stephen Pepper (1942) to designate symbols with great conceptual elaborating power. According to Pepper (cf Ortner 1973:1340) such a symbol provides a set of categories for conceptualizing other aspects of experience ${ }^{21}$.

In addition to the root metaphor as one type of key symbol in the elaborating mode, Ortner (1973:1341) describes another major type of elaborating symbol which she calls 'key scenarios.' This type is valued because it implies clear-cut modes of action appropriate to correct and successful living in the culture: 'they formulate the culture's basic means-ends relationships in actable form' (Ortner 1973:1341)22.

Having distinguished between these types of key symbols - root metaphors and key scenarios - Ortner (1973:1342) emphasizes that both types ultimately have the same kinds of referents, namely conceptual experience and action experience.

Summarizing symbols formulate basic orientations, and is directed at a different level of response - the level of attitude and commitment. 
Schematically Ortner's model looks as follows, and constitutes what Foster (1980:376) calls an asymmetrical model and Ortner herself (1973:1343) calls an 'unbalanced structure':

\section{Summarizing symbol vs Elaborating symbol \\ Root metaphor Key scenario}

To answer the question whether and when some symbol is 'key,' we must take into account the internal organization of the system of cultural meaning, as that system functions for actors leading their lives in the culture. Ortner $(1973: 1344)$ claims that her scheme suggests the modes of symbolic analysis relevant to the different types of key symbols:

A summarizing symbol is 'key' to the system when its substantive meanings have certain kinds of priority relative to other meanings of the system. Analysis of such symbols would entail a range of questions applicable to the cultural conversion of complex ideas into various kinds of relatively undifferentiated commitment, that is, patriotism or faith.

An elaborating symbol is 'key' to the system with regard to the power of its formal or organizational role in relation to the system. Analysis of the first type, root metaphors, requires questions applicable to the analysis of metaphor in the broadest sense, namely how thought proceeds and organizes itself through analogies, models, images, et cetera. Analysis of the second type of elaborating symbols, key scenarios, requires dramatistic modes of analysis through questions concerning the restructuring of attitudes and relationships as a result of enacting particular culturally provided sequences of stylized actions (cf the discussion on means-ends relationships above).

Foster (1980:376) criticizes Ortner for overlooking the most important differentiation between the two types of symbol. The meaning of both these symbolic types, she maintains, are connotative, but in summarizing symbols connotative features are covert, while in elaborating symbols they are overt. She argues as follows:

The latter (elaborating symbols - Van Staden) equates with simile, for the likeness is expressed, whereas in the former, a substitution of one thing for something similar takes place; in other words, it is the summarizing type that is a root metaphor and not the elaborating type, which is, instead, a root simile. 
The meaning of likeness is made explicit and is exploited for ideological purposes .... Summarizing symbols are interpretive of moral values, while elaborating symbols are expressive of them.

(Foster 1980:376)

On the basis of this insight Foster (1980:376) proposes that Ortner's asymmetrical model be adapted to take the following symmetrical form:

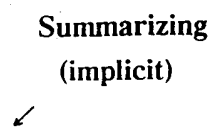

Root metaphor Metaphoric scenario

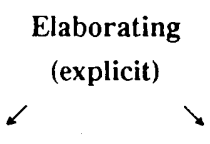

Root simile

Simile scenario

Foster (1980:382) states that the metaphoric linkage of events is the key to the symbolic mode - events are linked through time by means of analogy combined with affect. This fact, she concludes, explains why humans are able to respond with feelings to very abstract concepts. It also makes apparent the reason why aesthetic experiences, religion and play are particularly evocative of emotion: they are more directly and specifically analogical than the ordinary experiences of everyday life (Foster 1980:382). Important in symbol interpretation is the fact that simultaneity is paradigmatic in the symbolic mode: 'There is timelessness in events that are juxtaposed' (Foster 1980:383).

The model to be applied below will be based on this model of Ortner as amended by Foster, and will employ some of the insights discussed in this section 23 .

\section{THE MODEL APPLIED}

In applying the model first to the creation story in Genesis, and then in sequence to the New Testament, we in a sense preempt our findings. The assumption in following this method is that the expression 'image of God' should be interpreted as different types of symbol in the two contexts ${ }^{24}$. The purpose is to correctly tag it in terms of symbol type and to point out the implications of such a categorization. The model is constructed as follows:

* Identify the symbol by means of the five indicators for key symbols (cf 3.2.1 above). 
* Categorize the symbol according to one of the broad symbol types, that is, as a summarizing/elaborating symbol. In order to do this, employ Kay's concepts of unique beginners (key/core symbols) or inclusive taxa with their terminal taxa (cf 3.1).

* Determine to which of the derived categories the symbol should be assigned, e $\mathbf{g}$ the Root metaphor or the Metaphor scenario, and what the line of action should be, if any (cf 3.2.2 above).

\subsection{The creation story}

Gn 1:26-27 speaks about God creating man in his image. Some sort of relationship between God and man is established by this account. The question that has been pursued by many scholars up to now is whether the creation story suggests an analogy of being (analogia entis) or an analogy of relationship (analogia relationis) (cf 1.1 and 2.1 above). Our purpose is to determine what exactly is symboled in this account, by what symbol. In order to establish what the symbol $(\mathrm{X})$ is, we apply the 'indicators of cultural interest' (cf 3.2.1 above), taking 'the natives' to be the information provided by the Old Testament and other (contemporary and modern) sources 25 .

The concept of the image of God is taken up in a negative sense throughout the whole of the Old Testament, with the directive that no image of God will be tolerated, because man had never seen the form of God. Severe punishments are promised and meted out if anyone breaks this taboo (cf 2 above). This satisfies the fifth condition for the identification of a symbol, namely the appearance of greater cultural restrictions surrounding $X$, either in sheer number of rules, or severity of sanctions regarding its misuse, ' $X$ ' being God in this instance.

Nevertheless, as many scholars have pointed out, there is an abundance of 'descriptions' of God in anthropomorphic terms (cf 2.1 above). This satisfies the fourth condition for the identification of a symbol, namely the appearance of greater cultural elaboration surrounding $X$, that is, elaboration of vocabulary, or elaboration of details of X's nature, ' $\mathrm{X}$ ' being God.

The whole of the Old Testament is an account of God's involvement on many levels with creation, including and especially man. This satisfies the third condition for symbol identification, namely the appearance of $\mathrm{X}$ in many different contexts. These contexts may be behavioral or systemic: $\mathrm{X}$ comes up in many different kinds of action situation or conversation or $\mathrm{X}$ comes up in many different symbolic domains (myth, ritual, art, formal rhetoric, etc), ' $\mathrm{X}$ ' being God. 
The second condition, that the natives seem positively or negatively aroused about $X$, rather than indifferent, is abundantly attested to by the information, ' $X$ ' being God.

Finally, the 'natives' themselves tell us that $X(G o d)$ is culturally important (cf Dt $6: 4$, amongst many). This complies with the first condition for symbol identification.

In conclusion to this analysis we have to ask: If there were to be no concrete symbol of God in Israel - in contradistinction to the religious practices of Israel's neighbours - how was Israel to conceive of their God? Taking into account the results of our preceding symbol identification program the answer to this question, I believe, is: They had to conceive of God in terms of abstract symboling. God himself became the summarizing symbol for the whole of Israelite religious and social life (cf the definition of a summarizing symbol in 3.2.2 above).

The interesting question that follows from the symbol identification and classification according to type (i e, summarizing symbol), is: If God is taken as the key symbol (or unique beginner, cf discussion above), what is man's relationship to God according to this symbolic mode?

It has been indicated that various scholars agree that the term 'image' in the creation account would have been understood - at least partially - in a physical sense in ancient times (cf 2.1 and 2.2). Taking a summarizing symbol to belong in the paradigmatic dimension of symbolism where the symbol is organized around metaphor, which implies a relationship of partial likeness (cf 3.1 above), God is the all-inclusive taxon of which human(kind) is the less-inclusive taxon of which the gender split in man and woman is the terminal taxon (cf 3.1 above). This means that man belongs to the genus 'God' in this symbolic code. The fact that the taboo on making any kind of image of God is extended to include man (Dt 4:16) 26 , can probably be explained by the indications from the analysis that man is - symbolically - an extension of God. From the application of the model thus far one could therefore deduce that the relationship between God and man was conceived of as a 'kinship' one in the Priestly document, and perhaps throughout the Old Testament.

Having demonstrated that within the paradigmatic symbolic mode 'God' functions as a (sacred) summarizing symbol, it remains to determine to which category the symbol(s) could be assigned in terms of the symmetrical model proposed by Foster (cf above). In terms of the definition of root metaphor as symbols with great elaborating power that provide a set of categories for conceptualizing other aspects of experience, we have to designate the symbol 'God' as a summarizing symbol of the root metaphor kind. The model, however, requires an additional designation to become symmetrical. Within the context of the description if the creation of man, it is man who completes the binary structure of the summarizing symbol by being categorized as a symbol of the metaphoric scenario type. The implication of this designation is that man as the scenario type symbol is required to act out everything that is ascribed to God as root 
metaphor. In man-as-symbol the covert connotative meanings associated with God-assymbol are substantiated. Being 'kin' to God symbolically, as the model shows, man has the responsibility to act like God in real life.

\subsection{The New Testament: A change of image}

The New Testament exhibits a radical departure from the Old Testament in respect of the understanding of the image of God. The first and most obvious difference is that Christ is substituted for man as the image. In the same manner as above it can be shown that Christ as metaphoric scenario symbol was understood as 'kin' to God (as root metaphor symbol), and that in Jesus Christ the covert connotative meanings associated with the root metaphor symbol was substantiated. But that is not the only difference. As soon as man is brought into the equation, there is a major shift as to the kind of symbol that applies. Man's relationship to God is no more understood as a 'kinship' one, but as a mediated one. This means that man is not part of the symmetric summarizing symbol any more. He has forfeited that place. There is no need to argue whether man has lost the image, and whether the Old Testament indicates that in some indirect way (cf Von Rad 1964:392). The fact that Christ is simply substituted for man clearly shows that, whatever the Old Testament may have indicated, amongst the Christians it was understood that man had lost that position, and that would be true also symbolically. In 2 Cor 3:12-18 Paul repeatedly uses the term 'veil' ( $\tau \dot{o} \kappa \alpha \dot{\lambda} \nu \mu \mu \alpha)$ to argue that man has lost the capacity to understand God, but that Christ removes the veil for everyone who believes in him. Within the context of the discussion the 'veil' could probably be taken to refer to the image of God in man - lost, but regainable through Christ. This signifies a restructuring of (sacred) symbols in New Testament thought. In terms of the symmetrical model it could be shown as follows:

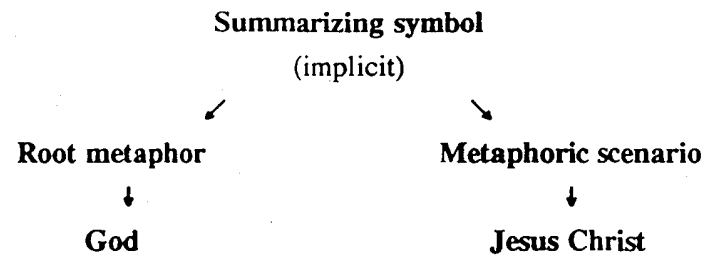

However, at this stage we must refer to the definition of symbolism (cf 3.1 above). It is said there that symbolism is a representative act, but at the same time that there is never a simple, direct relationship between symbol and what is symbolized. Symbols are, in actuality, complexly interrelated through analogical bonds. 
This complexity becomes quite clear when one has a close look at the way in which Jesus Christ is portrayed in the relevant passages. Much emphasis is placed upon the fact that Christ is the image of the invisible God and superior to creation (Col 1:15), preexistent (Col 1:17), embodying the full nature of God (Col 1:19). He is called 'God's secret' (Col 2:2) and it is explicitly stated: 'For in him the whole fullness of deity dwells bodily' (Col 2:9 - RSV).

The relationship between Christ and God posited in these references is so close that it is much more than the 'relationship of partial likeness' appropriate for man (cf preceding discussion). In fact, it could be described as a relationship of identity. To give expression to this relationship of identity, Christ would symbolically have to be conceived of as sharing the summarizing symbol of the root metaphor type with God. Schematically this would be expressed as follows:

\section{Summarizing symbol} (implicit)

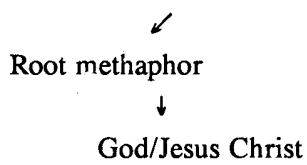

Where does man fit into this new symbolic map? In order to explain this, one has to consider the position of man vis-à-vis Christ. It is said repeatedly that man has to be changed, renewed, born again, become one with Christ (cf inter alia Col 3:10). From this we can deduce that Christ as symbol has an efficacious function for man. Thereby we are immediately transposed from the realm of the summarizing symbol to that of the elaborating symbol, within which iwo symbol types are differentiated, namely root similes and simile scenarios (cf 3.2.2). Analysis of root similes requires questions about how thought proceeds and organizes itself through analogies, models, images, et cetera; analysis of simile scenarios requires questions about the restructuring of attitudes and relationships as a result of culturally provided sequences of stylized action (cf 3.2.2 above).

Steering by these definitions we are able to ascertain that in his relationship to man Christ functions as a root simile. Being the image of God, and by virtue of that identity correspondence part of the paradigmatic dimension of symbols, Christ as symbol is simultaneously expressive of moral values, and therefore part of the syntagmatic dimension of symbols which focuses on problem-solving (cf 3.1). Man, conversely, belongs to the simile scenario, where the values located in the root simile are 
belongs to the simile scenario, where the values located in the root simile are dramaturgically acted out in 'sequences of stylized action' (see preceding discussion). Within the realm of the Christian community, where these symbols actually function, the 'culturally provided sequences of ... action' consist of (interpersonal) behavior that complies with the moral values 'imaged' by the root simile symbol, namely Christ. It is also clear from this argument that the 'man' who is under discussion is not 'humankind' any more, as in the creation story. 'Man' is the inclusive taxon of the genus 'believer in Christ'. The terminal taxa of this inclusive taxon are: man, woman, Gentiles, Jews, circumcised and uncircumsized ... (Col 3:11). Schematically our completed model would look like this:

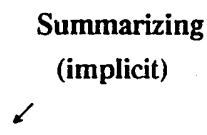

Root metaphor
Metaphoric scenario

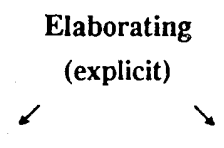

Root simile

Simile scenario

\section{CONCLUDING REMARKS}

It seems clear, in terms of the model, that the concept of 'image of God' has undergone some revision in terms of symbolic mode and symbol categorization in its New Testament context, compared to the Genesis account.

The analysis seems to validate the thesis that the concept image of God has acquired in its New Testament context - as a symbol within the syntagmatic symbolic mode - a connotative meaning that bears almost exclusively on responsible ethical behavior in acting out the example of the root simile, Jesus Christ. We have also seen; however, that the dissemination of the symbol 'Christ' covers the whole (Christian) symbolic plane. In the sense of the symbol 'Christ's' identity with the root metaphor 'God,' man's vocation in life is still to 'act like God.' It is perhaps important, however, to point out that this Biblical concept should not be employed as a political slogan to further general humanistic ideals. It has been shown that the symbol of man as the 'image of God' is applicable only to the more inclusive taxon of 'believers in Christ.' Even though this taxon may potentially include all of mankind without prejudice and without distinction, the New Testament does not understand this symbol to automatically apply to mankind on account of their being created by God. That is the Old Testament view, which is altered decisively by the New Testament ${ }^{27}$.

The primary consequence of the change in the symbol set that underlies the concept image of God in the New Testament, is the theological insight that man in general is precluded from claiming a certain ontological status on the basis of being made in the 
image of God. That status can only be regained through a faith relationship with Jesus Christ, which is the same as having that relationship with God. No rights can be demanded on the grounds of the 'image', for the image of God pertains to the believers in Jesus Christ only. At the same time man-in-Christ (the believer) acquires the responsibility to act out the values embodied in the root simile, Jesus Christ, namely love, caring and compassion.

\title{
ENDNOTES
}

1 Mauser (1970:338-339, with reference to Philo Quod Deus immutabilis sit 11,53) states:

\begin{abstract}
No Jew of New Testament times was more sensitive to the force of philosophical arguments against anthropomorphisms than Philo of Alexandria ... The most solid reason stands behind the recognition that the sentence 'God is not like man' must claim exclusive validity ... He (Philo - PvS) explained anthropomorphic modes of speech in the Old Testament as pedagogical devices on Moses' part for the benefit of simpleminded Israelites who could be educated only with the help of crude stories.
\end{abstract}

Fossum (1989:188; see also McCasland 1950:92-93; Kittel 1964:394; Wilson 1974:360; Wildberger 1976:562) points out that Philo frequently identifies the divine image after which man was created as the Logos, and that the likeness to God in man is to be found in the mind.

For more substantial discussions of Philo's position on this subject, see Fossum (1985:203208), Horowitz (1979:190-193) and Hanson (1982) (particularly the chapter entitled 'The analogy of pre-existence').

2 Gnosticism continued the genuinely Jewish tradition that the divine likeness of man was to be found in the body (Fossum 1989:188). The anthropos myth describes the creation of the Anthropos as the image of God. As the Urmensch emanating from the High God, he was essentially one with him: 'As the Anthropos figure was the image of God, so man was the image of the Anthropos, who lived in man as his true or inner self' (Wilson 1974:360). Some scholars take the view that the 'image of God' concept has a Gnostic background. In a review article Lohmann (1971:515; cf also Schnackenburg 1973:120-130) summarizes Peter Schwanz's viewpoint 'dass der paulinisch-deuteropaulinische Eikon-Begriff - mit ausnahme seiner ethische Relevanz nicht direkt aus dem AT über das Spätjudentum herleitbar, sondern nur vor dem Hintergrund der gnostischen Eikon-Vorstellung voll verständlich ist ..., For an in-depth discussion of Gnosticism on this subject, see Fossum (1985:231-239) and Hughes (1989:237-248). 
3 For discussions on Origen, Basil the Great, Gregory of Nyssa, Ambrose and Augustine - on the narrower but related issue of whether the Patristic tradition viewed woman as in the image of God, and with the focus on prelapsarian man and woman — , see Horowitz (1979:193-204). For general discussions on the Patristic literature, see McCasland (1950:94-96). For a specific discussion on the 'Trinitarian image' proposed by Augustine, see Hill (1984:207-215; Hughes 1989:16-17).

4 See Wilken (1992/3) for a discussion of medieval theology, with reference to Patristic literature as well as reformational theology.

5 For a discussion of Catholic and Protestant thoughts on the 'image' measured against medieval thought, see Evans (1988:74-78).

For a discussion of the image of God in Calvin's theology, see Crawford (1966:233-234), Prins (1972), Zachmann (1990).

For a general discussion of the concept in Protestant theology, see Kaufman (1956), Boer (1990, especially the chapter entitled 'The split of the Imago Dei in reformed theology,' page 152168).

6 There is even mention of a doctrine of the 'image of God' (cf Horst 1950:259), who calls it the biblical doctrine of the image of God. See also Hill (1984:196), Wildberger (1965:245).

7 Texts are quoted from the Revised Standard Version, CCAT texts.

8 In the LXX translation the terms $\varepsilon i k \omega \nu$ and $\dot{o} \mu \circ \omega \sigma \iota \varsigma$ are used.

9 Cf also Horst (1950:259-261), Porteous (1962:683), Kleinknecht (1964:389-390), Eichrodt (1967:123), Von Rad (1972:58), Plantinga (1988:53-54), Steenburg (1988:79).

10 Cf also Von Rad (1964:391), Köhler (1966:135), Eichrodt (1967:122), Eckert (1989:339), Hughes (1989:10-14).

11 In a discussion on anthropomorphisms Ulrich Mauser (1970:337-338) indicates that criticism of Old Testament anthropomorphisms in Judaism actually predates the formation of the New Testament and the Christian Church.

12 Wilson (1974:357) formulates: ' $2 \mathrm{Co}^{4}$ and Col $1^{15}$ depart most radically from the Old Testament use of the image of God'.

13 That is part of a process indicated in a model for the synchronic analysis of an ancient society as proposed by Elliot (1993), following Carney (1975). 
14 For the use of the terms syntagmatic and paradigmatic as both linguistic and nonlinguistic modes, Foster (1980:373) indicates her indebtedness to Hjelmslev (1953). She concludes that a paradigmatic construct (or p-structure) is an abstract organizing principle that cannot be actualized, but can generate s-structures, i e, 'realized syntagmatic sequences' (Foster 1980:373).

15 For further discussion on the importance of metaphorical language in theology, cf inter alia Van Aarde (1991), Mcfague (1983), Ricoeur (1978). In a response to the article of Van Aarde, Esler (1991) suggests additional reading of Sacks (1978), Wheelwright (1962) and Black (1962). See also the informative contribution by Malina (1991) for a reading theory perspective.

16 Foster (1980:374) offers the example of the gender designation of men versus the marital status designation of women:

Liberated woman has recently come to object to being classified as man in accordance with standard, taxonomic usage. Human or person is being substituted for man in many anthropological texts: a conscious, syntagmatic choice of a different member of a paradigm. In address forms, women object to semantic labeling by marital status, since men are not thus designated. A new address form $-M s-$ was devised to replace both Miss and Mrs, expanding the paradigm for the time being, but potentially reducing it if the replacement proves successful.

17 Ortner (1973:1338) refers to terms being used by other scholars which are roughly equivalent to the term 'key symbol': 'themes,' 'focal values,' 'dominant values,' 'integrative concepts,' 'dominant orientations.' Studies of meaning systems focused on 'the symbolic units which formulate meaning' specifically, use the terms 'core symbols' or 'dominant symbols.'

18 Ortner identifies the work of Schneider (1968) on American kinship as a good example of this approach.

19 Ortner (1973:1339) cites the following as 'public' symbols: cattle among the Dinka and Nuer; the Naven ritual of the Iatmul; the Australian churinga; the slametan of the Javanese; the forked stick of Ndembu rituals; the wheel-image in Tibet; food among the Sherpas.

20 She emphasizes that it is a continuum with the ideal types at both ends.

21 Ortner cites the central role of cattle in Dinka thought as an excellent example of a cultural root metaphor, and points out that Mary Douglas has shown that the living organism in some form functions as a root metaphor in many cultures — as a source of categories for conceptualizing social phenomena. This has undergone some change - in mechanized society the machine is a 
root metaphor for the social process, and in modern times it is the computer (cf Ortner 1973:1341).

22 Ortner quotes the Horatio Alger myth as an example of a key scenario in American culture the story of a poor boy of low status who achieves the American conception of success - wealth and power (=ends) - through hard work (=means).

23 The epistemological discussion was necessarily brief and selective. For a more fundamental understanding of the subject wider reading is essential, especially in the field of symbolism.

24 Well aware of the danger of oversimplification, I count the occurrences of the concept 'image of God' in Genesis as one, because in all three instances where the expression appears, it derives from the same author.

25 In this case the nature of the 'native's information' seems to dictate that we apply the 'rules' for symbol identification in the reverse order from which they were proposed by Ortner (cf 3.2.1.).

26 Note that the same terms are used in Dt 4:16 - when a prohibition is placed on the making of images of man himself as male and female - as those used in the creation account of Gn 1:27 (LXX text):

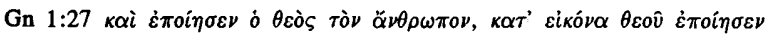

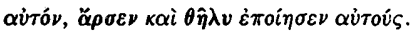

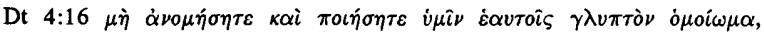

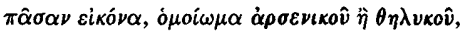

27 A possible application of this conclusion may be to determine in what way the symbolic imagery of the concept of man as the 'image of God' might function in a real-life context that may be homogeneous in one respect ( $\mathrm{i}$ e, Christian faith), but diverse in others (e g culture, gender or class).

\section{Works Consulted}

Barrett, C K 1971. The first epistle to the Corinthians. London: Adam \& Charles Black.

Berkhof, H 1973. Christelijk Geloof: Een inleiding tot de geloofsleer. Nijkerk: Callenbach.

Black, M 1962. Models and metaphors. Ithaca: Cornell University Press. 
Boer, H R 1990. An ember still glowing: Humankind as the image of God. Grand Rapids: Eerdmans.

Bolinger, D 1968. Aspects of language. New York: Harcourt.

Carney, T F 1975. The shape of the past: Models and antiquity. Lawrence, Kansas: Coronado Press.

Cohen, A 1932. Everyman's Talmud. London: Dent.

Conzelmann, H 1969. Der erste Brief an die Korinther. Göttingen: Vandenhoeck. 1976. Der Brief an die Kolosser, in Friedrich 1976:176-202.

Crawford, R G 1966. The image of God. Expository Times 77/8, 233-236.

Douglas, M 1966. Purity and danger. New York: Praeger.

Eckert, J 1989. Christus als 'Bild Gottes' und die Gottebenbildlichkeit des Menschen in der paulinischen Theologie, in Frankemölle \& Kertelge 1989:337-357.

Eichrodt, W 1967. Theology of the Old Testament. Vol 2. Translated from the German by John Baker. London: SCM.

Elliott, J H 1993. What is social-scientific criticism? Minneapolis: Fortress.

Esler, P F 1991. Response to Van Aarde (1991). Neotestamentica 25/1, 173-174.

Evans, C S 1988. Healing old wounds and recovering old insights: Toward a Christian view of the person for today, in Noll \& Wells 1988:68-86.

Fossum, J 1985. Gen. 1,26 and 2,7 in Judaism, Samaritanism, and Gnosticism. Journal for the Study of Judaism 16/2, 202-239.

1989. Colossians $1.15-18 \mathrm{a}$ in the light of Jewish mysticism and gnosticism. NTS 35, 183-201.

Foster, M L 1980. The growth of symbolism in culture, in Foster \& Brandes 1980:371-397.

Foster, M L \& Brandes, S H (eds) 1980. Symbol as sense: New approaches to the analysis of meaning. San Francisco: Academic Press.

- 1980. Introduction to Part 1: Sense and non-sense, in Foster \& Brandes 1980:3-7.

Frankemölle, H \& Kertelge, K (Hrsg) 1989. Vom Urchristentum zu Jesus: Joachim Gnilka zum 60. Geburtstag am 8. Dezember 1988. Freiburg: Herder.

Friedrich, G (Hrsg) 1976. Die Briefe an die Galater, Epheser, Philipper, Kolosser, Thessalonicher und Philemon. Göttingen: Vandenhoeck. (NTD 8.)

Hanson, A T 1982. The image of the invisible God. London: SCM.

Hill, E 1984. Being human: A biblical perspective. London: Geoffrey Chapman.

Hjelmslev, L 1953. Prolegomena to a theory of language. Indiana University $\mathrm{Pu}-$ blications in Anthropology and Linguistics. (Memoir 7 of the International Journal of American Linguistics.) 
Horowitz, M C 1979. The image of God in man - is woman included? Harvard Theological Review 72/3-4, 175-206.

Horst, F 1950. Face to face: The biblical doctrine of the image of God. Interp. 4/3, 259-270.

Hughes, P E 1989. The true image: The origin and destiny of man in Christ. Grand Rapids: Eerdmans.

Jones, A A 1962. s v Image. NBDict.

Kaufman, G D 1956. The Imago Dei as man's historicity. The Journal of Religion $36 / 3,157-168$.

Kay, P 1971. Taxonomy and semantic contrast. Language 47, 866-887.

Kittel, G 1964. s v $\varepsilon i \kappa \omega \nu$. TDNT.

Kleinknecht, H 1964. s v $\varepsilon i k \omega \nu . T D N T$.

Kline, M G 1978. Investiture with the image of God. Westminster Theological Journal XL, 39-62.

Köhler, L 1966. Theologie des Alten Testaments. Tübingen: Mohr.

Lohmann, T 1971. Review article on Schwanz, P 1970. Theologische Literaturzeitung 96/7, 515-517.

Lohse, E 1977. Die Briefe an die Kolosser und an Philemon. Göttingen: Vandenhoeck.

Malina, B J 1981. The New Testament world: Insights from cultural anthropology. Atlanta: John Knox.

- 1991. Reading theory perspective: Reading Luke-Acts, in Neyrey 1991:3-23.

Mauser, U 1970. Image of God and incarnation. Interp. 24/3, 336-356.

McCasland, S V 1950. 'The image of God' according to Paul. JBL 69, 85-100.

McFague, S 1983. Metaphorical theology: Models of God in religious language. London: SCM.

Neyrey, J H (ed) 1991. The social world of Luke-Acts: Models for interpretation. Peabody: Hendrickson.

Noll, M A \& Wells, D F (eds) 1988. Christian faith \& practice in the modern world: Theology from an evangelical point of view. Grand Rapids: Eerdmans.

Ortner, S B 1973. On key symbols. American Anthropologist 75, 1338-1346.

Pepper, S 1942. World hypotheses. Berkeley: University of California Press.

Plantinga, C (Jr) 1988. Images of God, in Noll \& Wells 1988:51-67.

Pokorný, P 1991. Colossians: A commentary. Peabody: Hendrickson.

Porteous, N W 1962. s v Image of God. IDB.

Prins, R 1972. The image of God in Adam and the restoration of man in Jesus Christ: A study in Calvin. Scottish Journal of Theology 25/1, 32-44. 
Ricoeur, P 1978. The rule of metaphor: Multi-disciplinary studies of the creation of meaning in language. London: Routledge \& Kegan Paul.

Rogers, J (ed) 1988. Medical ethics, human choices: A Christian perspective. Scottdale, Pennsylvania: Herald Press.

Sacks, S (ed) 1978. On metaphor. Chicago: University of Chicago.

Schnackenburg, R 1973. Review article on P Schwanz (1970). Biblische Zeitschrift $17,129-130$.

Schneider, D M 1968. American kinship. Englewood Cliffs: Prentice-Hall.

Schwanz, P 1970. Imago Dei als christologisch-anthropologisches Problem in der Geschichte der Alten Kirche von Paulus bis Clemens von Alexandrien. Halle/ Saalen: Niemeyer.

Sperber, D 1980. Is symbolic thought prerational?, in Foster \& Brandes (eds) 1980: 25-36.

Steenburg, D 1988. The case against the synonymity of morphe and eikon. Journal for the Study of the New Testament 34, 77-86.

Van Aarde, A G 1991. 'The most high God does live in houses, but not houses built by men ...': The relativity of the metaphor 'temple' in Luke-Acts. Neotestamentica 25/1, 51-64.

Van der Watt, J G 1988. Christus is julle hoop: Die brief aan die Kolossense - 'n semantiese redevoeringsanalise. Pretoria: NG Kerkboekhandel.

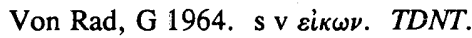
1972. Genesis. London: SCM.

Wendland, H-D 1972. Die Briefe an die Korinther. Göttingen: Vandenhoeck.

Wheelwright, P 1962. Metaphor and reality. Bloomington: Indiana University Press.

Wildberger, H 1965. Das Abbild Gottes. Theologische Zeitschrift 21/4, 245-259. 1976. s v צֶלֶ THAT.

Wilken, R L i992/3. The image of God: A neglected doctrine. People Dynamics 11, 292-296.

Wilson, S G 1974. New wine in old wineskins: IX. Image of God. The Expository Times 85, 356-361.

Zachmann, R C 1990. Jesus Christ as the image of God in Calvin's theology. Calvin Theological Journal 25/1, 45-62. 